\title{
ORIGINAL
}

\section{Delayed Diagnosis of Primary Bone and Soft Tissue Tumors Initially Treated as Degenerative Spinal Disorders}

\author{
Toshihiko Nishisho', Toshinori Sakai', Fumitake Tezuka ${ }^{1}$, Kosaku Higashino', Shoichiro Takao ${ }^{3}$, Yoichiro Takata ${ }^{1}$, \\ Ryo Miyagi', Shunichi Toki ${ }^{1}$, Mitsunobu Abe ${ }^{2}$, Kazuta Yamashita' ${ }^{1}$, Akihiro Nagamachi' ${ }^{1}$, and Koichi Sairyo ${ }^{1}$
}

\begin{abstract}
${ }^{1}$ Department of Orthopedics, Institute of Biomedical Sciences Tokushima University Graduate School, Tokushima, Japan, ${ }^{2}$ Department of Orthopedics, Tokushima Prefectural Central Hospital, Tokushima, Japan, ${ }^{3}$ Department of Radiology, Institute of Biomedical Sciences Tokushima University Graduate School, Tokushima, Japan
\end{abstract}

\begin{abstract}
Background Symptoms of primary bone and soft tissue tumors located in the trunk mimic those of degenerative spinal disorders such as low back pain or pain or numbness of the legs. Due to their rarity, especially in sarcoma located in the trunk, diagnosis is sometimes delayed. Methods A retrospective review was performed of the records of 383 patients with primary bone and soft tissue tumors who visit our out patient clinic from 2011 to 2013 at a single institution. Patients with delayed diagnosis of primary bone and soft tissue tumors initially treated as degenerative spinal disorders for more than 2 months were identified. Results Of the 383 patients, 5 (1.3\%) were initially diagnosed as having degenerative spinal disorders. All 5 patients had bone or soft tissue tumors in the lumbar spine or pelvis. Three patients had a malignant tumor (osteosarcoma, chondrosarcoma, or small round cell sarcoma) at the progressive stage, and 1 died of lung metastasis. Two patients had a benign tumor (aneurysmal bone cyst or simple bone cyst). Conclusions Our findings suggest that when low back pain and leg pain are refractory to conservative treatment, further radiological examination should be conducted. J. Med. Invest. 63 : 274-277, August, 2016
\end{abstract}

Keywords : Delayed diagnosis; Primary bone and soft tissue tumors in the trunk; Degenerative spinal disorders

\section{INTRODUCTION}

Symptoms of primary bone and soft tissue tumors located in the trunk sometimes mimic those of degenerative spinal disorders such as low back pain (LBP) or pain or numbness of the legs. In particular, LBP is a common symptom in people of all ages and is typically caused by degenerative spinal disorders such as lumbar disc herniation or lumbar spinal canal stenosis. About two thirds of adults suffer from low back pain at some time (1) and has an annual incidence of $63.7 \%$ (2). In a study of adults in the Mediterranean, 266 (39.5\%) had experienced LBP and 166 (24.6\%) had experienced sciatica during the previous 6 months (3).

Compared with degenerative spinal disorders, musculoskeletal tumors are rare, with malignant bone tumors comprising only $0.5 \%$ of all malignancies in humans and soft tissue sarcomas having an incidence of $1.5-2 \%$ (4). The annual incidence of bone sarcoma is 8-9 per million population, while that of soft tissue sarcoma is about 30 per million population (5). Due to their rarity, the correct diagnosis of such tumors is sometimes delayed. Moreover, patients with primary bone or soft tissue tumors located in the trunk are sometimes initially treated for degenerative spinal disorders. A delayed diagnosis, especially of sarcoma in the trunk, could negatively impact patient prognosis $(5,6)$. In this study, we investigated cases of delayed diagnosis of primary bone and soft tissue tumors initially treated as degenerative spinal disorders before the correct diagnosis was made.

Received for publication April 13, 2016 ; accepted June 27, 2016.

Address correspondence and reprint requests to Toshihiko Nishisho, Department of Orthopedics, Institute of Biomedical Sciences Tokushima University Graduate School, 3-18-15 Kuramoto-cho, Tokushima 7708503, Japan and Fax : +81-88-633-0178.

\section{PATIENTS AND METHODS}

We retrospectively reviewed the records of 383 patients with primary bone and soft tissue tumors who visit our outpatient clinic from 2011 to 2013 at a single institution. Patients with delayed diagnosis of primary bone and soft tissue tumors who had been treated for degenerative spinal disorders for more than 2 months were identified by reviewing hospital stay documentation. Patients diagnosed as having distant metastasis were excluded. The delay between onset and definite diagnosis, primary symptoms, initial diagnosis, tumor identification, pathological diagnosis, tumor progression, treatment, and prognosis were investigated. This study was approved by the Ethics Committee of Tokushima University.

\section{RESULTS}

Of the 383 patients, 5 ( $1.3 \%$; 1 man and 4 women ; mean age, 35.5 years ; range, $14-75$ years) had been treated for degenerative spinal disorders before consulting our hospital (Table 1). There were 88 trunk patients in the 383 patients, 39 patients of bone tumor (sternum 4, clavicle 1, rib 7, scapula 1, thoracic spine 1 , lumbar spine 3 , sacrum 6 , coccyx 1 , ilium 8 , pubis 5 , ischium 2 ) and 49 patient of soft tissue tumor (thoracic wall 10 , shoulder 11 , axilla 2 , back 9 , abdominal wall 2 , lumbar region 3 , abdominal cavity 1 , retroperitoneum 2 , inguinal region 2 , buttock 7 ). All the 5 patients of delayed diagnosis had bone or soft tissue tumors in the lumbar spine or pelvis. Three patients had a malignant tumor (osteosarcoma, chondrosarcoma, or small round cell sarcoma) at the progressive stage, and 1 patient died of lung metastasis. Two patients had a benign tumor (aneurysmal bone cyst or simple bone cyst). The initial symptoms in all cases were LBP, leg pain, and buttock pain, which were similar to those of degenerative spinal disorders. Two patients had been treated for simple LBP, 1 for 
Table 1 Patient datails

\begin{tabular}{|c|c|c|c|c|c|c|c|c|c|c|c|c|}
\hline Case & Age & Sex & Local & $\begin{array}{c}\text { Final } \\
\text { diagnosis }\end{array}$ & Biopsy & $\begin{array}{c}\text { Tumor } \\
\text { progression }\end{array}$ & Prognosis & Symptom & $\begin{array}{c}\text { Initial } \\
\text { diagnosis }\end{array}$ & $\begin{array}{c}\text { Periods } \\
\text { of } \\
\text { delay } \\
\text { (months) }\end{array}$ & $\begin{array}{c}\text { Exami- } \\
\text { nation by } \\
\text { which } \\
\text { tumor was } \\
\text { identified }\end{array}$ & Treatment \\
\hline 1 & 71 & $\mathrm{~F}$ & ilium & $\begin{array}{c}\text { osteo- } \\
\text { sarcoma }\end{array}$ & $\begin{array}{l}\text { needle } \\
\text { biopsy }\end{array}$ & $\begin{array}{l}\text { lung } \\
\text { metastases }\end{array}$ & DOD & $\begin{array}{l}\text { low back } \\
\text { pain } \\
\text { limb pain }\end{array}$ & $\begin{array}{l}\text { spondylo- } \\
\text { listhesis }\end{array}$ & 4 & $\mathrm{CT}$ & $\begin{array}{l}\text { palliative } \\
\text { treatment }\end{array}$ \\
\hline 2 & 75 & $\mathrm{~F}$ & ilium & $\begin{array}{l}\text { chondro- } \\
\text { sarcoma } \\
\text { grade } 2\end{array}$ & $\begin{array}{c}\text { open } \\
\text { biopsy }\end{array}$ & $\begin{array}{l}\text { hip joint } \\
\text { invasion }\end{array}$ & AWD & limb pain & sciatic pain & 36 & $\begin{array}{l}\text { Plain X- } \\
\text { ray }\end{array}$ & $\begin{array}{l}\text { treatment } \\
\text { refusal }\end{array}$ \\
\hline 3 & 38 & $\mathrm{~F}$ & $\begin{array}{c}\text { retro- } \\
\text { peritoneum }\end{array}$ & $\begin{array}{l}\text { small } \\
\text { round cell } \\
\text { sarcoma }\end{array}$ & $\begin{array}{c}\text { open } \\
\text { biopsy }\end{array}$ & $\begin{array}{l}\text { vertebrae } \\
\text { invasion }\end{array}$ & AWD & $\begin{array}{c}\text { low back } \\
\text { pain }\end{array}$ & lumbago & 4 & MRI & $\begin{array}{l}\text { Chemo- } \\
\text { therapy }\end{array}$ \\
\hline 4 & 15 & $\mathrm{~F}$ & sacrum & $\begin{array}{c}\text { aneurysmal } \\
\text { bone cyst }\end{array}$ & $\begin{array}{c}\text { open } \\
\text { biopsy }\end{array}$ & $\begin{array}{c}\text { extraosseous } \\
\text { expansion }\end{array}$ & $\mathrm{CDF}$ & $\begin{array}{l}\text { buttock } \\
\text { pain }\end{array}$ & $\begin{array}{l}\text { Lumbar } \\
\text { disc } \\
\text { herniation }\end{array}$ & 4 & MRI & $\begin{array}{l}\text { curettage } \\
\text { and bone } \\
\text { grafting }\end{array}$ \\
\hline 5 & 14 & $\mathrm{M}$ & $\begin{array}{l}\text { lumbar } \\
\text { vertebra }\end{array}$ & $\begin{array}{c}\text { simple } \\
\text { bone cyst }\end{array}$ & none & none & AWD & $\begin{array}{c}\text { low back } \\
\text { pain }\end{array}$ & lumbago & 2 & MRI & observation \\
\hline
\end{tabular}

Abbreviations. DOD : dead of disease ; AWD : alive with disease ; CDF : continuous disease ; CT computed tomography ; MRI : magnetic resonance imaging

spondylolisthesis, 1 for common sciatica, and 1 for lumbar disc herniation at a mean time of 10 months (range, 2-36 months) before the definitive diagnosis was made. Tumors were finally identified on magnetic resonance imaging (MRI) in 3 patients, computed tomography (CT) in 1 patient, and plain radiography in 1 patient.

Four patients had bone tumors and 1 patient had a soft tissue tumor with bone invasion. In addition, 1 patient had distant metastasis and 3 patients presented with local progression when the definite diagnosis was made. Four of the 5 patients underwent biopsy to establish histological diagnosis. Palliative treatment was performed in 1 patient, chemotherapy in 1 , and curettage and bone grafting in 1 . The patient with distant metastasis died of disease, 1 patient was disease free, and 3 patients were alive with disease.

\section{CASE PRESENTATIONS}

\section{Case 1 (Figure 1)}

A 71-year-old woman who had undergone radiotherapy for carcinoma of the cervix uteri 30 years ago presented with a 4 -month history of left buttock and thigh pain. She consulted a neurosurgeon who diagnosed degenerative lumbar spondylolisthesis and scheduled posterior lumbar fusion. Although plain radiography revealed an abnormal heterogeneous sclerotic lesion in the sacrum and posterior pelvis, it was considered to be a side effect of radiotherapy. However, preoperative imaging revealed a bone tumor of the ilium and multiple lung metastases, and laboratory tests showed elevated levels of alkaline phosphatase $(>10,000 \mathrm{IU} / \mathrm{l})$ and D-dimer $(>10 \mathrm{mg} / \mathrm{ml})$. She was referred to our department where needle biopsy of the bone tumor revealed conventional osteosarcoma, for which she underwent local palliative radiotherapy. Six months after the correct diagnosis, she died of progressive lung metastasis.

\section{Case 4 (Figure 2)}

A 15-year-old girl with severe left buttock pain had been treated conservatively after being diagnosed as having lumbar disc herniation, but her symptoms persisted. After consulting another doctor, plain radiographs revealed a destructive sacral lesion, and MRI revealed a multilocular cyst. Her laboratory data were normal. She was referred to our department where biopsy revealed an aneurysmal bone cyst. Consequently, she underwent curettage and artificial bone grafting and her symptoms improved. Thirty months after the operation, no recurrence was apparent.

\section{DISCUSSION}

Primary bone and soft tissue tumor, especially in the spine and pelvis, is a relatively rare disease and difficult to recognize. Börm et al. reported that of 2,013 patients with spinal tumors referred for operative treatment, $10(0.5 \%)$ were initially misdiagnosed as having a degenerative disorder (7). Wurtz et al. reported that in 30 of 68 patients (44\%) with pelvic sarcoma, an inaccurate diagnosis was initially made (8). Early and correct diagnosis of primary bone and soft tissue tumors can improve patient survival $(9,10)$. In this study, 5 of 383 patients (1.3\%), including 3 with malignancy, were treated for degenerative spinal disorders before a correct diagnosis was made.

The delayed diagnosis of primary bone and soft tissue tumors located in the trunk can be attributed to several factors. Symptoms of LBP, buttock pain, and leg pain are non-specific to tumors and are more common in degenerative spinal disorders. Furthermore, compared with tumors located in the extremities, those in the spine and pelvis are located in deep parts of the trunk. Therefore, tumors may remain silent and undetected until developing into a large mass.

In the case of a patient complaining of LBP or buttock pain, plain radiography alone of the lumbar spine is typically considered sufficient, but even when plain radiographs of the pelvis are taken, early recognition of bone abnormalities is difficult (8). In the present retrospective study, only 1 tumor was identified on plain radiography ; CT or MRI was needed to detect the tumors in the other 4 cases. Although plain radiography is useful for initial survey, further imaging modalities such as CT or MRI are essential for making an early diagnosis of bone and soft tissue tumors.

Regarding laboratory data, Case 1 (osteosarcoma) showed extraordinarily elevated levels of alkaline phosphatase. Although no specific laboratory tumor marker for bone and soft tissue sarcoma exists, laboratory tests can be helpful for diagnosing a specific disease, such as that in Case 1. In addition, further imaging modalities are typically required to identify benign tumors or low-grade 

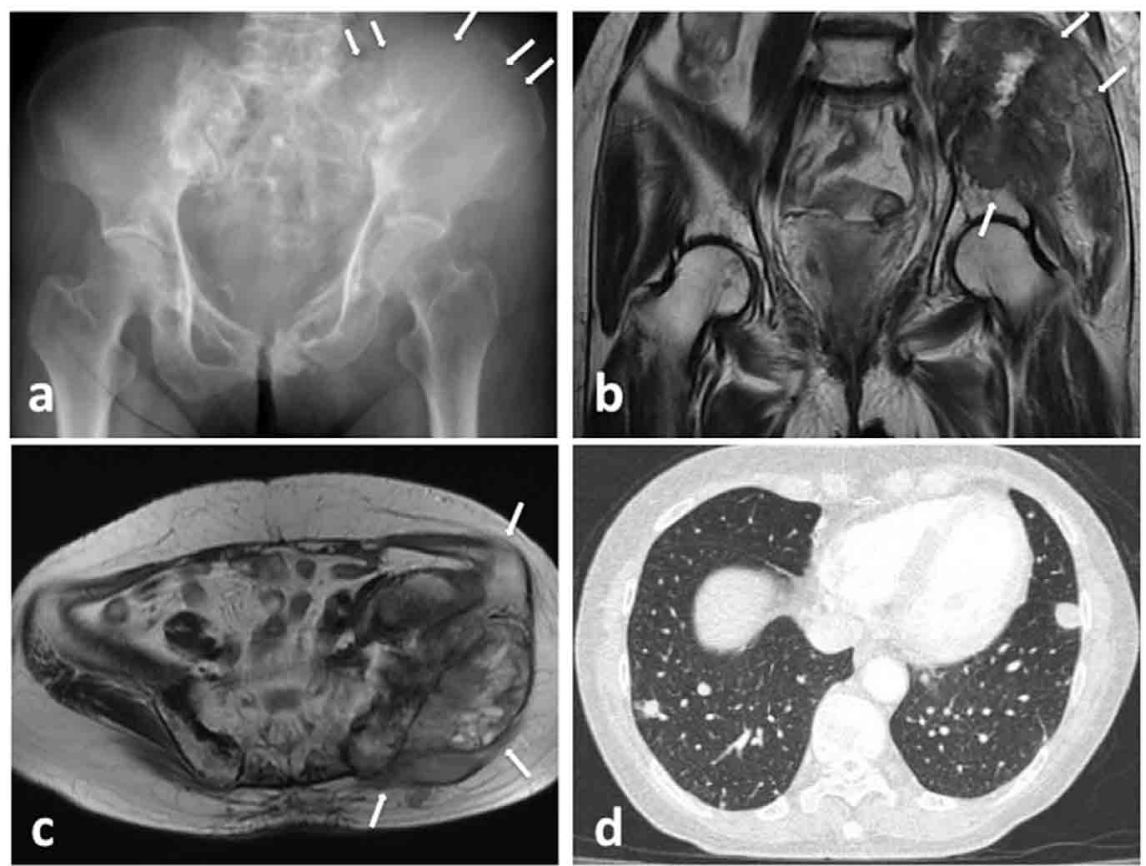

Figure 1. Case 1, pelvic osteosarcoma

$\mathrm{a}$ : Plain radiographs showing an abnormal lesion on the posterior left ilium. b, $\mathrm{c}$ : Magnetic resonance images showing a huge mass in the left pelvis expanding into soft tissues. $\mathrm{d}$ : Computed tomography (CT) images showing multiple lung metastases.
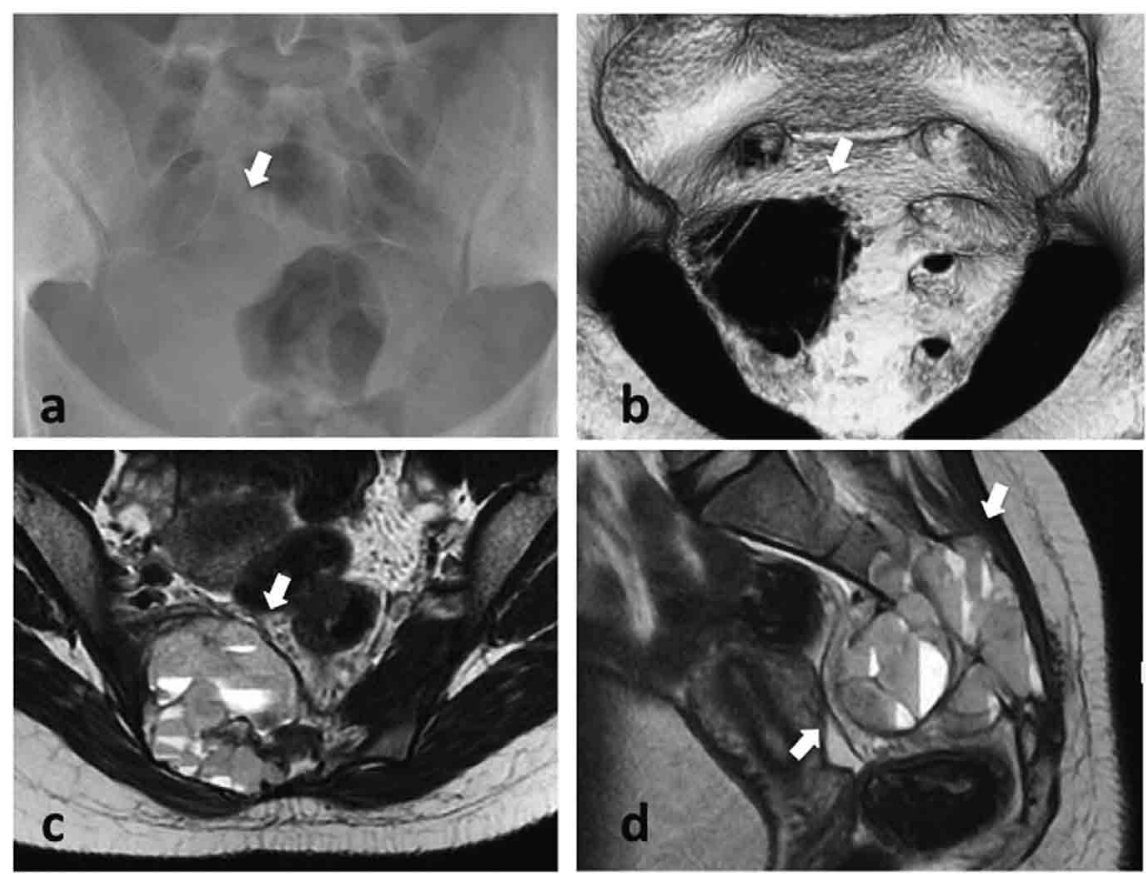

Figure 2. Case 4, sacrum aneurysmal bone cyst

$\mathrm{a}, \mathrm{b}$ : Plain radiographs and $\mathrm{BD}-\mathrm{CT}$ showing a lytic lesion in the right sacrum. $\mathrm{c}, \mathrm{d}$ : MRI showing multiple fluid-fluid levels in the sacrum expanding into the anterior and posterior soft tissue of the sacrum.

\section{sarcoma.}

The present study revealed that when LBP and leg pain are refractory to conservative treatment, or some abnormality is found on plain radiography or in laboratory data, further radiological examinations could help to avoid a delayed diagnosis of primary bone and soft tissue tumors. The patients with pain at rest or severe tenderness need immediate image examination such as plain radiograph. The patients who have a continuous pain at the second visit need further examination. We recommend second visit after one week or two week for all patient. Although MRI is a little bit expensive examination, it is essential to obtain accurate diagnosis, not only for tumors but also for degenerative disorders. Since the 
symptom of pelvic tumors resembles lumbar spinal disease, the most important thing is to check pelvis when the patient complaint a lumbago.

\section{ACKNOWLEDGEMENT}

None

\section{CONFLICT OF INTEREST}

None (for all authors).

\section{REFERENCES}

1. Deyo RA, Weinstein JN : Low back pain. The New England journal of medicine 344(5) : 363-70, 2001

2. Laslett M, Crothers C, Beattie P, Cregten L, Moses A: The frequency and incidence of low back pain/sciatica in an urban population. The New Zealand medical journal. [Research Support, Non-U.S. Gov't] 104(921) : 424-6, 1991

3. Korovessis P, Repantis T, Zacharatos S, Baikousis A: Low back pain and sciatica prevalence and intensity reported in a Mediterranean country : ordinal logistic regression analysis. Orthopedics 35(12) : e1775-84, 2012

4. Ofluoglu O, Boriani S, Gasbarrini A, De Iure F, Donthineni R : Diagnosis and planning in the management of musculoskeletal tumors : surgical perspective. Seminars in interventional radiology 27 (2) : 185-90, 2010

5. Grimer RJ, Briggs TW : Earlier diagnosis of bone and softtissue tumours. The Journal of bone and joint surgery British volume 92(11) : 1489-92, 2010

6. Smith GM, Johnson GD, Grimer RJ, Wilson S : Trends in presentation of bone and soft tissue sarcomas over 25 years : little evidence of earlier diagnosis. Annals of the Royal College of Surgeons of England 93(7) : 542-7, 2011

7. Borm W, Gleixner M, Klasen J : Spinal tumors in coexisting degenerative spine disease-a differential diagnostic problem. European spine journal : official publication of the European Spine Society, the European Spinal Deformity Society, and the European Section of the Cervical Spine Research Society. [Case Reports] 13(7) : 633-8, 2004

8. Wurtz LD, Peabody TD, Simon MA : Delay in the diagnosis and treatment of primary bone sarcoma of the pelvis. The Journal of bone and joint surgery American volume. [Case Reports] 81(3) : 317-25, 1999

9. Kim MS, Lee SY, Cho WH, Song WS, Koh JS, Lee JA, Yoo JY, Shin DS, Jeon DG : Prognostic effects of doctor-associated diagnostic delays in osteosarcoma. Archives of orthopaedic and trauma surgery 129(10): 1421-5, 2009

10. Nakamura T, Matsumine A, Matsubara T, Asanuma K, Uchida A, Sudo A : The symptom-to-diagnosis delay in soft tissue sarcoma influence the overall survival and the development of distant metastasis. Journal of surgical oncology 104(7) : $771-5,2011$ 